\title{
Heritability and Genetic Correlations of Test Day Milk Yield and Composition, Individual Laboratory Cheese Yield, and Somatic Cell Count for Dairy Ewes
}

\author{
M. H. Othmane, ${ }^{1}$ L. F. De La Fuente, J. A. Carriedo, and F. San Primitivo \\ Departamento de Producción Animal I \\ Universidad de León, 24071 León, Spain
}

\begin{abstract}
Genetic parameters for milk yield, contents of fat, total protein, casein and serum protein, individual laboratory cheese yield, and somatic cell counts (SCC) were estimated from 7492 monthly test-day records of 1119 Churra ewes. Estimates were from multivariate REML using analytical gradients (AG-REML) procedures. Except for fat content, estimates for the other routinely recorded traits (milk yield, protein content, and SCC) agreed with those previously obtained in this and other dairy sheep populations. Protein content and composition had the highest heritabilities and repeatabilities. Heritabilities for protein and casein contents were very similar ( 0.23 and 0.21 , respectively), and genetic correlation between the traits was close to unity (0.99). Accordingly, casein content is not advisable as an alternative to protein content as a selection criterion in dairy ewes; it does not have any compelling advantages and costs more to measure. Individual laboratory cheese yield (ILCY) obtained with Churra ewes had a low heritability (0.08), suggesting that potential for selection for this parameter would be possible but is not recommended. All correlations with ILCY were high and positive except for milk yield. A high SCC was accompanied by an increase in serum protein content and involved a loss in milk yield.
\end{abstract}

(Key words: genetic parameter, test-day milk component, dairy ewe)

Abbreviation key: FTD = flock test date, $\mathbf{I L C Y}=$ individual laboratory cheese yield.

\section{INTRODUCTION}

Ewes' milk is rich in useful materials, resulting in good cheese yield, which explains its transformation

Received October 27, 2000.

Accepted July 8, 2002.

Corresponding author: F. San Primitivo; email: dplfst@unileon.es.

${ }^{1}$ National Agronomic Research Institute of Tunisia (INRAT), 2049 Ariana, Tunis, Tunisia. only into cheese. Cheese yield from ewes' milk is nearly twice that obtained from cows' or goats' milk (Assenat, 1985). To improve the cheese yield of ewe's milk, it may be most desirable to examine actual cheese yield. However, it is difficult to estimate cheese yield directly from small, individual milk samples as recorded for dairy ewes. Alternate measures have been tested to increase cheese yield, such as its relationships with rheological parameters or selection for the routinely recorded milk composition traits (fat and protein contents). Both the coagulation properties (Remeuf et al., 1991) and the fat and protein contents (Delacroix-Buchet et al., 1994) seem useful but insufficient to determine yield and quality of the final product.

The protein content and composition of milk are important to the cheese manufacturer because they are major factors in determining yield and quality of the final product (Ng-Kwai-Hang et al., 1981; Hurtaud et al., 1993). However, no information is available on the inheritance of casein and serum protein contents and their genetic relationships with the other milk traits and cheese yield. Furthermore, protein fractions do not contribute in the same way towards milk-cheese transformation; the casein content forms part of the curd, whereas the serum protein remains in the whey fraction.

Little attention has been paid to protein fractions in dairy ewes (Fuertes et al., 1998), and no studies have been carried out on individual laboratory cheese yield (ILCY). Determining casein and individual cheese yield for a large number of milk samples-as required for genetic studies-has not been feasible because of the complexity and labor intensity of the analysis and the difficulty in automating the process. Consequently, no genetic studies have been done for these variables in dairy ewes.

Presently, determining ILCY and casein and serum protein contents can be automated by Fourrier transformed infrared spectroscopy, and, therefore, test-day data for these traits may then be available for each ewe. Automation with an acceptable rate (35 to 40 samples/h) makes genetic studies possible. Thus, genetic 
parameters for these variables may be estimated to understand the relationships between ILCY and milk components that affect cheese yield (especially casein content).

The SCC of milk is a good indicator of the existence of subclinical mastitis (Gonzalo et al., 1994; Fuertes et al., 1998), and SCC are beginning to be used in mastitis control programs for ewes. For dairy ewes, data on the inheritance of SCC and its relationship with milk yield and composition is scarce, and no studies have been carried out on its relationship to cheese yield. The few available genetic studies are limited to the Churra and Lacaune breeds (Baro et al., 1994; Barillet et al., 1999; El-Saied et al., 1999).

For milk fat content, results from several previous studies on all indigenous Spanish breeds indicated very low genetic variances. Heritability and repeatability estimates for fat content always are lower than those reported for other components, such as protein content (Jurado et al., 1995). Even in some experiments specifically designed to check repeatability for fat content, De La Fuente et al. (1997) obtained results that did not agree with the literature. The three factors most likely to cause such results are management conditions (dependent on the stockbreeder's knowledge), poor data collection, or a possible inadequate analysis of milk samples. In this study, we collected, transported, and analyzed milk samples at the dairy plant of León University to avoid these effects on our study of fat content in Churra ewes.

Genetic parameters for test-day ILCY, protein content, casein content, serum protein content, fat content, SCC, and milk yield were estimated for dairy ewes. These genetic parameters allow us to reexamine the use of milk composition in selection for dairy sheep.

\section{MATERIALS AND METHODS}

\section{Data Collection and Analysis}

Milk yield of dairy ewes is defined by the production in the milking period only after $1 \mathrm{mo}$ of suckling. Consequently, only the decreasing part of the lactation curve is recorded while milk solids concentration increases throughout that period (Barillet and Boichard, 1987).

Individual milk samples were taken at approximately monthly intervals from eight dairy flocks of the National Association of Spanish Churra Breeders (ANCHE) between April, 1997, and July, 1999. All flocks were on the alternate a.m.-p.m. plan of testing, and all ewes were milked twice daily. The first test-day record was obtained at least $3 \mathrm{~d}$ after weaning of the lamb (between $d 31$ and 75 postpartum). Subsequent records were obtained at approximately monthly intervals thereafter. Milk samples we analyzed in the dairy plant of the León University Animal Production Department to ensure accurate determination of milk composition.

Upon arrival at the laboratory, samples were analyzed after they were warmed to $40^{\circ} \mathrm{C}$ and stirred. Contents of fat, true protein, casein, and serum protein were determined by the mid infrared FTIR method using an AEGYS MI 200 (ANADIS, Trappes, France) spectrometer. The instrument was calibrated against known sample standards (Gerber for fat and Kjeldahl for true protein, casein, and serum protein) according to the norm of the International Dairy Federation (IDF, 1964, 1996), which was modified for use with ovine milk. This modification consisted of increasing the acetic acid concentration to $20 \%$ to reach the isoelectric point of the caseins in ovine milk. The ILCY was determined for each test-day milk sample. All samples were previously equilibrated at $30^{\circ} \mathrm{C}$ before rennet was added. ILCY was measured as follows: $10 \mathrm{ml}$ of individual preheated and homogenized milk were curdled for $1 \mathrm{~h}$ at $37^{\circ} \mathrm{C}$. To facilitate rennet distribution in milk, the rennet was diluted 10-fold with bidistilled water before adding it to the milks. ILCY was thus measured; the coagulum (cottage cheese + whey) was centrifuged for $15 \mathrm{~min}$ at $2500 \mathrm{rpm}$ after longitudinal cutting, and the whey was removed after draining for $45 \mathrm{~min}$ (test tube face down; the curd remained at the bottom of the tube). ILCY was defined as the weight of the centrifuge residue (curd obtained after expulsion of whey and draining in the open air) expressed in kilograms per $100 \mathrm{~L}$ of milk. This method was previously described and contrasted by Othmane (2000). The SCC was determined by the Fossomatic method as described by Gonzalo et al. (1993). Data for milk yield and SCC were supplied by ANCHE. From the ANCHE data file, other information included date of milk sampling, date of birth of ewe, lambing date, and lambing type (single or multiple born lambs).

The data consisted of 7492 test-day records of 1119 ewes (from two generations). The mean number of test days per lactation was 3.75 , and each ewe averaged 1.8 lactations. The total number of sheep in pedigree was 2213 , of which 2029 were ewes and 184 were rams. Of the total rams, $32 \%$ were used for natural service under good pedigree (three generations) control and $68 \%$ were used for AI; all AI rams had offspring in different flocks. Therefore, many genetic links existed among flocks because of the wide use of rams through AI. Pedigree data were verified by the genetic improvement unit of León University Animal Production Department using DNA markers.

\section{Statistical Analysis}

For data analysis, records of SCC were transformed to their logarithmic form (LnSCC) for hypothesis test- 
ing (Ali and Shook, 1980). To account for the circumstances of the day of test within flock, contemporary groups were formed on the basis of flock test date (FTD) (Ptak and Schaeffer, 1993). The test-day traits analyzed (dependent variables) were fat, protein, casein, and serum protein contents, SCC, milk yield, and ILCY. The data were analyzed with the following multitrait repeatability animal model:

$$
\mathrm{y}_{\mathrm{ijklmn}}=\mu+\mathrm{FTD}_{\mathrm{i}}+\mathrm{SL}_{\mathrm{j}}+\mathrm{LG}_{\mathrm{k}}+\mathrm{LT}_{\mathrm{l}}+\mathrm{A}_{\mathrm{m}}+\mathrm{PE}_{\mathrm{m}}+\mathrm{e}_{\mathrm{ijklmn}}
$$

where

$\mathrm{y}_{\mathrm{ijk} k m n}=$ dependent variable; $\mu=$ population mean; FTD $_{\mathrm{i}}$ $=$ fixed effect of flock test date $\mathrm{i} ; \mathrm{SL}_{\mathrm{j}}=$ fixed effect of stage of lactation $\mathrm{j} ; \mathrm{LG}_{\mathrm{k}}=$ fixed effect of lambing age $\mathrm{k}$; $\mathrm{LT}_{1}=$ fixed effect of lambing type $1 ; \mathrm{A}_{\mathrm{m}}=$ random additive genetic effect of the individual $\mathrm{m} ; \mathrm{PE}_{\mathrm{m}}=$ random permanent environmental effect on the individual $\mathrm{m}$; and $\mathrm{e}_{\mathrm{ijk} k \mathrm{mn}}=$ random residual effect.

All known relationships among individuals were considered in the animal model. There were 113 levels for FTD. Age of ewe consisted of four subclasses: 1 (between 1 and $2 \mathrm{yr}$ old), 2 (between 2 and $3 \mathrm{yr}$ ), 3 (between 3 and $4 \mathrm{yr}$ ), and 4 (>4 yr). Stage of lactation was classified into five subclasses, each 1 mo long. There were two subclasses for lambing type: single and multiple.

The random permanent environmental effect $(\mathrm{PE})$ includes the effect common to all records of the same ewe. The random effect for lactation was not included in the model because of the low number of lactations per ewe (1.8) in our study. The model employed in this study for test-day records corresponds to the most simple model discussed by Ptak and Schaeffer (1993).

Genetic parameters were estimated by the analytical gradients (AG) REML procedure (Neumaier and Groeneveld, 1998) using the Variance Component Estimation programs, VCE4 package (Groeneveld, 1998).

\section{RESULTS AND DISCUSSION}

Means and standard deviations of the test-day traits are in Table 1. Similar results for milk yield and fat and protein contents were reported for dairy ewes (Gonzalo et al., 1994; Cappio-Borlino et al., 1997; Ploumi et al., 1998). Means for protein fractions (casein and serum protein) were also similar to those reported by Fuertes et al. (1998) for Churra ewes but higher than those obtained by Pellegrini et al. (1997) for Lacaune ewes.

The arithmetic mean for SCC $\left(749 \times 10^{3}\right.$ cells $\left./ \mathrm{ml}\right)$ was in agreement with recent values reported for Churra ewes (El-Saied et al., 1998) and much lower than that recorded in other flocks of the same breed without any
Table 1. Arithmetic means $(\overline{\mathrm{x}})$, standard deviations (SD), and residual standard deviations (RSD) of the test-day traits.

\begin{tabular}{|c|c|c|c|}
\hline Trait & $\overline{\mathrm{x}}$ & $\mathrm{SD}^{1}$ & $\mathrm{RSD}^{2}$ \\
\hline Milk yield, $\mathrm{ml} / \mathrm{d}$ & 956 & 400 & 155 \\
\hline Fat, g/L & 71.2 & 14.4 & 12.5 \\
\hline Protein, g/L & 59.8 & 6.0 & 4.8 \\
\hline Casein, g/L & 47.6 & 5.3 & 4.4 \\
\hline Serum protein, g/L & 12.0 & 1.1 & 0.9 \\
\hline $\mathrm{ILCY}^{3}, \mathrm{~kg} / 100 \mathrm{~L}$ & 26.5 & 4.3 & 3.99 \\
\hline LnSCC & 12.1 & 1.5 & 1.18 \\
\hline
\end{tabular}

${ }^{1}$ Derived from the sum of the additive genetic, permanent environmental, and residual variances obtained from the VCE analysis.

${ }^{2}$ From VCE.

${ }^{3} \mathrm{ILCY}=$ Individual laboratory cheese yield.

mastitis control program (Baro et al., 1994; Gonzalo et al., 1994). The ILCY value obtained from this study $(26.5 \mathrm{~kg} / 100 \mathrm{~L})$ is within the range of those reported for commercial cheese yield in dairy ewes (Anifantakis and Kaminarides, 1983; Pirisi et al., 1999), although it deals with a different manufacturing process. However, there are no previous studies of individual cheese yield on a laboratory scale. Laboratory cheese yield, like that of cottage cheese, usually tends to be higher than industrial cheese yield, perhaps because of the very reduced milk amounts manufactured and the forced draining of the cottage cheese, which captures even the smallest curd that may be lost with the whey in the industrial process. Draining seems more suitable during commercial manufacture; it lasts about $12 \mathrm{~h}$, depending on the type of cheese, whereas whey removal in the laboratory is accelerated by centrifugation, which can have a negative influence on adequate whey evacuation.

Heritability, permanent environmental variance proportion, and repeatability estimates for test-day variables are in Table 2. These estimates were lower than those reported for dairy cows (Abdallah and McDaniel, 2000), where selection programs are more advanced and the production levels are higher. It was observed in dairy cows that heritability estimates increased with increased production (Van Vleck et al., 1988). However, our estimates fall within the range frequently obtained for dairy ewes (except fat content). Furthermore, our results were probably influenced by the enormous variability in milking practices and management for the Churra breed (e.g., hand stripping, nutrition), and the possible effects of poor sample collection.

With regard to fat content, heritability was especially low (0.06), as was that obtained by Jurado et al. (1995) in the Spanish Manchega breed. However, this result was much lower than those reported by Barillet and Boichard (1987) and Barillet et al. (1999) for the French Lacaune breed. The same trend occurs with the repeatability value $(0.26)$. In addition, milk fat content vari- 
Table 2. Heritabilities $\left(\mathrm{h}^{2}\right)$, proportions of permanent environmental variance $\left(\mathrm{c}^{2}\right)$ and repeatabilities $(\mathrm{r})$ for test-day traits.

\begin{tabular}{llllll}
\hline Trait & $\mathrm{h}^{2}$ & $\mathrm{SE}$ & $\mathrm{c}^{2}$ & $\mathrm{SE}$ & $\mathrm{r}$ \\
\hline Milk yield, ml/d & 0.15 & 0.03 & 0.25 & 0.03 & 0.40 \\
Fat, g/L & 0.06 & 0.04 & 0.20 & 0.05 & 0.26 \\
Protein, g/L & 0.23 & 0.07 & 0.12 & 0.07 & 0.35 \\
Casein, g/L & 0.21 & 0.07 & 0.12 & 0.06 & 0.33 \\
Serum protein, g/L & 0.16 & 0.07 & 0.16 & 0.06 & 0.32 \\
ILCY $^{1}, \mathrm{~kg} / 100 \mathrm{~L}$ & 0.08 & 0.04 & 0.08 & 0.05 & 0.16 \\
LnSCC & 0.11 & 0.05 & 0.23 & 0.06 & 0.34 \\
\hline
\end{tabular}

${ }^{1} \mathrm{ILCY}=$ Individual laboratory cheese yield.

ability seems especially influenced by feeding (Van Soest, 1963; Tyrrell and Moe, 1972; Sutton et al., 1980).

The heritability estimate for protein content $(0.23)$ was within the range reported for dairy ewes. This value was higher than previous estimates for the same breed but lower than estimates from other dairy ewes breeds such as Lacaune (Barillet and Boichard, 1987; Barillet et al., 1999) and Sarde (Casu et al., 1975). Estimates of heritability for this variable also seem heterogeneous in dairy cows (Meyer, 1985; Pander et al., 1992), varying between 0.25 and 0.71 .

Heritability for casein content (0.21) was close to that obtained for protein content (0.23). Coefficients of genetic variation [ratio of genetic standard deviation to phenotypic average (Barillet and Boichard, 1987; Carriedo et al., 1995)], which better represent the genetic gain possibilities, were also similar for both traits (5.1 and $4.8 \%$, respectively). However, the serum protein content had lower heritability $(0.16)$ because changes in protein composition due to various environmental factors are more important in serum protein content than in casein content (Grappin et al., 1981; Hayes et al., 1984). Protein content and composition were the most heritable milk composition parameters (Table 2).

We know of no studies of genetic parameters for individual cheese yield in dairy ewes. Our study showed low heritability (0.08) for ILCY. The low heritability and repeatability and the high variability of fat content undoubtedly influenced these results. These values also indicate the existence of other unidentified nongenetic factors, such as rennet strength, initial $\mathrm{pH}$, and atmospheric conditions, which control the efficacy of the transformation of milk into cheese.

The low heritability of SCC (0.11) was within the range of estimates (0.09 to 0.16) found for Churra and Lacaune ewes (Kennedy et al., 1982; El-Saied et al., 1998; Barillet et al., 1999) and for dairy cows (Banos and Shook, 1990; Schutz et al., 1994). These results indicate that improving management practices such as improved hygienic conditions seems the most appropriate way to reduce flock infection.
Repeatability estimates for protein content $(0.35)$ and milk yield (0.40) were consistent with those reported for dairy ewes (Delacroix-Buchet et al., 1994; Lagriffoul et al., 1994; Fuertes et al., 1998). Repeatabilities for casein and serum protein contents were 0.33 and 0.32 , respectively, with proportions of permanent environmental variance of 0.12 for both traits. We know of only two studies of repeatability for protein composition (casein and serum protein) in dairy ewes. These estimates were obtained from two experimental flocks in the Lacaune (Pellegrini et al., 1997) and Churra (Fuertes et al., 1998) breeds. The first study recorded results slightly higher than ours. The second, on the same breed, reported similar repeatability for casein content (0.37) but a very different value for serum protein content (0.03). The repeatability estimate for ILCY obtained from the present study was 0.16 . No previous values were found in the literature for individual cheese yield in dairy ewes. The low repeatability of ILCY suggested that the cheese-making process is impacted by minor changes. The repeatability value for LnSCC (0.34) was consistent with those reported by El-Saied et al. (1998) for the same breed and Lagriffoul et al. (1994) for the Lacaune breed.

Genetic correlations among test-day milk yield, fat content, protein content, casein content, serum protein, ILCY, and LnSCC are in Table 3. Genetic correlations between milk yield and composition traits were clearly negative (-0.53 to -0.72). The literature for dairy ewes (Barillet and Boichard, 1987; El-Saied et al., 1998) and dairy cows (Boichard and Bonaïti, 1987; Roman and Wilcox, 2000) indicates a similar trend for the correlation between milk yield and milk composition. However, the negative association between milk yield and protein content may be stronger in dairy ewes than in dairy cows.

Negative genetic associations between milk yield and contents of protein and casein $(-0.62$ and -0.72 , respectively) suggest that those traits must be included in selection programs if their levels are to be maintained while increasing milk yield. If such composition traits 
Table 3. Genetic (below the diagonal) and phenotypic (above the diagonal) correlations among test-day traits studied.

\begin{tabular}{lcccrrrr}
\hline Trait $(\mathrm{i} / \mathrm{j})^{1}$ & 1 & 2 & 3 & \multicolumn{1}{c}{4} & \multicolumn{1}{c}{5} & \multicolumn{1}{c}{6} & 7 \\
\hline 1 Milk yield, ml/d & & -0.43 & -0.41 & -0.39 & -0.36 & -0.20 & -0.14 \\
2 Fat, g/L & -0.63 & & 0.62 & 0.62 & 0.40 & 0.37 & 0.04 \\
3 Protein, g/L & -0.68 & 0.80 & & 0.99 & 0.71 & 0.31 & 0.13 \\
4 Casein, g/L & -0.72 & 0.79 & 0.99 & & 0.62 & 0.31 & 0.12 \\
5 Serum protein, g/L & -0.53 & 0.73 & 0.97 & 0.97 & & 0.16 & 0.15 \\
6 ILCY ${ }^{2}, \mathrm{~kg} / 100$ L & -0.58 & 0.60 & 0.76 & 0.78 & 0.61 & & 0.04 \\
7 LnSCC & -0.36 & 0.04 & 0.13 & 0.09 & 0.20 & 0.33 & \\
\hline
\end{tabular}

${ }^{1} \mathrm{i} / \mathrm{j}=$ Trait $\mathrm{i}$ and trait $\mathrm{j}$.

${ }^{2} \mathrm{ILCY}=$ Individual laboratory cheese yield.

were considered, selection intensities for milk yield would be reduced. Because selection on casein or protein content would cause a decrease in milk yield and selection on milk yield leads to a decrease in both milk components, it seems preferable to use a combination of milk yield and casein content or milk yield and protein content as selection critera. Ewes with high SCC also tend to produce less milk and vice versa.

All genetic correlations among composition traits were positive and in the range of 0.60 to 0.99 . The highest correlations were among protein content and protein fractions. These traits are the most important factors for the ability of the milk to produce cheese (Storry et al., 1983; Schaar, 1984; Remeuf et al., 1991); casein content is the factor most responsible for differences in coagulation ability between milk samples. The strong correlation between protein and casein content, close to unity, expresses the strong relationship between both traits well. Furthermore, their genetic correlations with the ILCY were comparable in sign and magnitude ( 0.76 and 0.78 for protein and casein, respectively). From a genetic point of view, selection for protein content rather than selection for casein content may be preferable. Protein content is routinely recorded and is less difficult and less expensive to record when compared to casein.

Even though serum protein does not form part of the curd and is directly transferred to the whey fraction, the estimated genetic correlation between serum protein content and ILCY was high (0.61). This slightly surprising result was due to the high correlation between serum protein and casein (0.97). As expected, the higher solids milk produced a higher laboratory cheese yield. The ILCY had a large negative genetic correlation with milk yield (-0.58). However, ILCY had a high positive correlation with SCC (0.33). SCC and milk yield were negatively correlated $(-0.36)$. ILCY was also positively correlated with fat content.

The genetic correlation between fat and protein content $(0.80)$ indicated the strong association between both traits. Accordingly, selection for increased protein content will also induce a correlated increase in fat content. This result is of great interest for the Spanish sheep selection programs, where heritability estimates for fat content have been lower than those reported for other dairy sheep breeds.

The phenotypic correlation between SCC and serum protein content was in agreement with other studies (Andrews, 1983; Verdi et al., 1987; Pellegrini et al., 1997; Fuertes et al., 1998). A high SCC is associated with changes in quantity and activity of proteolytic enzymes in milk, and these proteases may damage the casein inducing the passage of soluble products of casein proteolyse to the liquid phase.

\section{CONCLUSIONS}

This study was the first to estimate genetic parameters for protein composition and ILCY in milk from ewes. The ILCY had low heritability and repeatability. Selection for ILCY is currently not recommended for the Churra breed. However, more research on other breeds of milking ewes would be useful to investigate the heritability of ILCY and its genetic relationship with milk components.

Protein fractions had the highest estimates of heritability and repeatability. Heritabilities and repeatabilities for protein and casein contents were similar and relatively high, suggesting they should be used as selection criteria for sheep used to produce cheese. However, given the high genetic correlation between protein and casein, and their relationships with ILCY, selection for protein content is recommended over selection for casein content.

Heritability and repeatability for fat content was low in spite of the precautions for sampling and milk analysis. Fat content may be more influenced by management and nutritional conditions in Churra sheep.

\section{ACKNOWLEDGMENTS}

This paper was developed within Spanish projects, AGF96-0819-CP and AGF96-1408-C03-01, financed by 
the Comision Interministerial de Ciencia y Tecnología (Madrid, Spain).

\section{REFERENCES}

Abdallah, J. M., and B. T. McDaniel. 2000. Genetic parameters and trends of milk, fat, days open, and body weight after calving in North Carolina experimental herds. J. Dairy Sci. 83:1363-1370.

Ali, A. K., and G. E. Shook. 1980. An optimum transformation for somatic cell concentration in milk. J. Dairy Sci. 63:487-490.

Andrews, A. T. 1983. Breakdown of casein in bovine milks with high somatic cell counts arising from mastitis or infusion with bacterial endotoxin. J. Dairy Res. 50:57-66.

Anifantakis, E. M., and S. E. Kaminarides. 1983. Contribution to the study of Halloumi cheese made from sheep's milk. Aust. J. Dairy Technol. 38:29-31.

Assenat, L. 1985. Le lait de brebis: composition et propriétés. Pages 281-319 in Lait et Produits Laitiers. I. Les laits de la mamelle à la laiterie F. M. Luquet, ed. Technique et Documentation Lavoisier, Schaar, 198.

Banos, G., and G. E. Shook. 1990. Genotype by environment interaction and genetic correlations among parities for somatic cell count and milk yield. J. Dairy Sci. 73:2563-2573.

Barillet, F., and B. Bonaïti. 1992. La production laitière: objectifs et critères de sélection. Pages $117-122$ in INRA Prod. Anim. $\mathrm{N}^{\circ}$ hors série. "Elements de génétique quantitative et appliquée aux populations animales".

Barillet, F., and D. Boichard. 1987. Studies on dairy production of milking ewes. II. Estimates of genetic parameters for total milk composition and yield. Génét. Sél. Evol. 19:459-474.

Barillet, F., R. Rupp, S. Mignon-Grasteau, J. M. Astruc, M. Jacquin, and G. Lagriffoul. 1999. Genetic analysis for mastitis resistance and somatic cell score in French Lacaune dairy sheep. Page 393399 in Milking and Milk Production of Dairy Sheep and Goats. EAAP Publ. 95. Wageningen pers, Wageningen, The Netherlands.

Baro, J. A., J. A. Carriedo, and F. San Primitivo. 1994. Genetic parameters of test day measures for somatic cell count, milk yield and protein percentage of milking ewes. J. Dairy Sci. 77:2658-2662.

Boichard, D., and B. Bonaïti. 1987. Genetic parameters for first lactation dairy traits in Friesian, Montbéliarde and Normande breeds. Génét. Sél. Evol. 19:337-350.

Cappio-Borlino, A., B. Portolano, M. Todaro, N. P. P. Macciotta, P. Giaccone, and G. Pulina. 1997. Lactation curves of Valle del Belice dairy ewes for yields of milk, fat and protein estimated with testday models. J. Dairy Sci. 80:3023-3029.

Carriedo, J. A., J. A. Baro, L. F. De la Fuente, and F. San Primitivo. 1995. Genetic parameters for milk yield in dairy sheep. J. Anim. Breed. Genet. 112:59-63.

Casu, S., R. Carta, and J. C. Flamant. 1975. Amélioration génétique de la production laitière des brebis Sarde. Ann. Génét. Sél. Anim. 7:73-90.

De la Fuente, L. F., F. San Primitivo, J. A. Fuertes, and C. Gonzalo. 1997. Daily and between-milking variations and repeatabilities in milk yield, somatic cell count, fat, and protein of dairy ewes. Small Ruminant Res. 24:133-139.

Delacroix-Buchet, A., F. Barillet, and G. Lagriffoul. 1994. Caractérisation de l'aptitude fromagère des laits de brebis Lacaune à l'aide d'un Formagraph. Lait 74:173-186.

El-Saied, U. M., J. A. Carriedo, and F. San Primitivo. 1998. Heritability of test day somatic cell counts and its relationship with milk yield and protein percentage in dairy ewes. J. Dairy Sci. 81:2956-2961.

El-Saied, U. M., J. A. Carriedo, L. F. De la Fuente, and F. San Primitivo. 1999. Genetic parameters of lactation cell counts and milk and protein yields in dairy ewes. J. Dairy Sci. 82:639-644.

Fuertes, J. A., C. Gonzalo, J. A. Carriedo, and F. San Primitivo. 1998. Parameters of test day milk yield and milk components for dairy sheep. J. Dairy Sci. 81:1300-1307.

Gabiña, D., F. Arrese, J. Arranz, and B. de Heredia. 1993. Average milk yields and environmental effects on Latxa sheep. J. Dairy Sci. 76:1191-1198.
Gabiña, D., and F. Barillet. 1991. Actual tendencies of dairy sheep selection within the E. C. C. Inf. Tec. Econ. Agraria 87(A):227234.

Gonzalo, C., J. A. Baro, J. A. Carriedo, and F. San Primitivo. 1993. Use of the Fossomatic method to determine somatic cell count in sheep milk. J. Dairy Sci. 76:115-119.

Gonzalo, C., J. A. Carriedo, J. A. Baro, and F. San Primitivo. 1994. Factors influencing variation of test day milk yield, somatic cell count, fat and protein in dairy sheep. J. Dairy Sci. 77:1537-1542.

Grappin, R. R. Jeunet, M. Brochet, and A. Taquin. 1981. Etude des laits de chèvre. I. Teneur du lait de chèvre en matière grasse, matière azotée et fractions azotées. Lait 61:117-133.

Groeneveld, E. 1998. VCE User's guide. Version 4.2. Institute of Animal Husbandry and Animal Sciences, Mariensee, Germany.

Hayes, J. F., K. F. Ng-Kwai-Hang, and J. E. Moxley. 1984. Heritability of milk casein and genetic and phenotypic correlations with production traits. J. Dairy Sci. 67:841-846.

Hurtaud, C., H. Rulquin, and R. Vérité. 1993. Effect of infused volatile fatty acids and caseinate on milk composition and coagulation in dairy cows. J. Dairy Sci. 76:3011-3020.

International Dairy Federation. 1964. Determination of the casein content of milk. IDF Doc. No. 29. Int. Dairy Fed., Brussels, Belgium.

International Dairy Federation. 1996. Whole milk: Determination of milk fat, protein and lactose contents. Guide for the operation of mid-infra-red instruments. IDF Doc. No. 141B. Int. Dairy Fed., Brussels, Belgium.

Jurado, J. J., M. Serrano, M. D. Pérez-Guzman, and V. Montoro. 1995. Improvements in the Manchega genetic breeding programme. Cah. Options Méditerr. (Vol. 11):133-141.

Kennedy, B. W., M. S. Sethar, A. W. Tong, J. E. Moxley, and B. R. Downey. 1982. Environmental factors influencing test-day somatic cell counts in Holsteins. J. Dairy Sci. 65:275-280.

Lagriffoul, G., D. Bergonier, X. Berthelot, M. Jacquin, P. Guillouet, and F. Barillet. 1994. Facteurs de variation génétiques et non génétiques des comptages de cellules somatiques du lait de brebis en relation avec les caractères laitiers et les mesures portant sur le lait de tank. Pages 149-155 in Somatic Cells and Milk of Small Ruminants. EAAP Publ. 77. Wageningen pers, Wageningen, The Netherlands.

Meyer, K. 1985. Genetic parameters for dairy production of Australian Black and White cows. Livest. Prod. Sci. 12:205-219.

Neumaier, A., and E. Groeneveld. 1998. Restricted maximum likelihood estimation of covariances in sparse linear models. Génét. Sél. Evol. 30:3-26.

Ng-Kwai-Hang, K. F., J. F. Hayes, J. E. Moxley, and H. G. Monardes. 1981. Environmental influences on protein content and composition of bovine milk. J. Dairy Sci. 64:1993-1998.

Othmane, M. H. 2000. Paramètres génétiques de la composition du lait de brebis et du rendement fromager en laboratoire. Ph.D. Diss., Univ. De León, León, Spain.

Pander, B. L., W. G. Hill, and R. Thompson. 1992. Genetic parameters of test day records of British Holstein-Friesian heifers. Anim. Prod. 55:11-21.

Pellegrini, O., F. Remeuf, M. Rivemale, and F. Barillet. 1997. Renneting properties of milk from individual ewes: Influence of genetic and non-genetic variables, and relationship with physiocochemical characteristics. J. Dairy Res. 64:355-366.

Pirisi, A., A. Fraghi, G. Piredda, and P. Leone. 1999. Influence of sheep $\mathrm{AA}, \mathrm{AB}$ and $\mathrm{BB} \beta$-lactoglobulin genotypes on milk composition and cheese yield. Pages 553-555 in Milking and Milk Production of Dairy Sheep and Goats. EAAP Publ. 95. Wageningen pers, Wageningen, The Netherlands.

Ploumi, K., S. Belibasaki, and G. Triantaphyllidis. 1998. Some factors affecting daily milk yield and composition in a flock of Chios ewes. Small Ruminant Res. 28:89-92.

Ptak, E., and L. R. Schaeffer. 1993. Use of test day yields for genetic evaluation of dairy sires and cows. Livest. Prod. Sci. 34:23-34.

Remeuf, F., V. Cossin, C. Dervin, J. Lenoir, and R. Tomassone. 1991. Relations entre les caractères physico-chimiques des laits et leur aptitude fromagère. Lait 71:397-421. 
Roman, R. M., and C. J. Wilcox. 2000. Bivariate animal model estimates of genetic, phenotypic, and environmental correlations for production, reproduction, and somatic cells in Jerseys. J. Dairy Sci. 83:829-835.

Schaar, J. 1984. Effects of $\kappa$-casein genetic variants and lactation number on the renneting properties of individual milks. J. Dairy Res. 51:397-406.

Schutz, M. M., P. M. VanRaden, and G. R. Wiggans. 1994. Genetic variation in lactation means of somatic cell scores for six breeds of dairy cattle. J. Dairy Sci. 77:284-293.

Storry, J. E., A. S. Grandison, D. Millard, A. J. Owen, and G. D. Ford. 1983. Chemical composition and coagulating properties of renneted milks from different breeds and species of ruminant. J. Dairy Res. 50:215-229.

Sutton, J. D., J. D. Oldham, and I. C. Hart. 1980. Products of digestion, hormones and energy utilization in milking cows given concentrates containing varying proportions of barley or maize. Pages
303-306 in Energy Metabolism. Ed. L. E. Mount, Bütterworths, London.

Tyrrell, H. F., and P. W. Moe. 1972. Net energy value for lactation of a high and low concentrate ration containing silage. J. Dairy Sci. 55:1106-1112.

Upadhyaya, T. N., and A. T. Rao. 1993. Diagnosis and threshold values of subclinical mastitis in goats. Small Ruminants Res. 12:201-210.

Van Soest, P. J. 1963. Ruminant fat metabolism with particular reference to factors affecting low milk and feed efficiency. A review. J. Dairy Sci. 46:204-226.

Van Vleck, L. D., M. C. Dony, and G. R. Wiggans. 1988. Genetic (co)variances for milk and fat yield in California, New York, and Wisconsin for an animal model by restricted maximum likelihood. J. Dairy Sci. 71:3053-3060.

Verdi, R. J., D. M. Barbano, M. E. Dellavalle, and G. F. Senyk. 1987. Variability in true protein, casein, non protein nitrogen and proteolysis in high and low somatic cell milks. J. Dairy Sci. 70:230-242. 